\title{
Supply Chain of Paddy and Wheat Seeds Production in Tarai Development Corporation and Private Seed Firms of Uttarakhand
}

\author{
Nikhil Pratap Singh ${ }^{1 *}$, Sarbananda Sahoo ${ }^{1}$ and Chandra Dev ${ }^{2}$ \\ ${ }^{1}$ Department of Commerce and Management, Shri Venkateshwara University, Gajraula, India \\ ${ }^{2}$ Department of Agricultural Economics, G. B. Pant University of Agriculture and Technology, \\ Pantnagar, India \\ *Corresponding author
}

\begin{tabular}{|l|}
\hline Ke y w o r d s \\
Supply chains, \\
Marketable surplus, \\
Linkages, \\
Challenges, \\
Distribution, \\
Dealers \\
\hline Article Info \\
\hline Accepted: \\
20 January 2021 \\
Available Online: \\
10 February 2021 \\
\hline
\end{tabular}

Keywords

Supply chains, Marketable surplus, Linkages,

Challenges,

Dealers

\section{Accepted:}

20 January 2021

10 February 2021

\section{A B S T R A C T}

Agriculture supply chains and their management are now evolving in India to respond to emerging new marketing situations in the wake of globalization. Efficient supply chains results to an increase in the marketable surplus by bringing down the inefficiencies in production, processing, storage and transportation. The study was conducted in Udham Singh Nagar district of Uttarakhand for the supply chain management of wheat and rice seed production by Tarai Development Corporation in Udham Singh Nagar to analyze the forward, backward integration of supply chain. The primary data were collected from Tarai Development Corporation, and private seed plant owners through personal interviews. Private seed plant owners were interviewed to find the practices followed by them from procurement till the marketing of seeds. The secondary data was collected from various published records/ publications and from selected seed producing companies. Tarai Development Corporation has an extensive network of dealers and retailers. Tarai Development Corporation caters its customers to a number of sales channels viz. private sales channel, government sales channel, institutional sales channel and direct sales channel. Seed companies have a very robust sales channel. The sales channels may vary from one firm to another. Dependence on a particular channel may vary but channel identified are moreover same. Market dynamics in seed industry is a crucial factor. There are high chances of delayed payment in case of any change in market scenario. This was a common problem that was faced by almost every company of the region of Uttarakhand and adjoining areas of Uttarakhand as well as Uttar Pradesh. The delivery and sales channels are moreover same as that of the Tarai Development Corporation. Sales channel of private seed companies can be categorized into three categories viz. private sales, institutional sales, direct sale. 


\section{Introduction}

India with its predominant rural base is considered as one of the world's oldest and largest agrarian country. Every aspect of the economy, polity and majority of its population are governed by the performance of agricultural sector. Agriculture is an important sector of Indian economy as it contributes about $15.20 \%$ to the total GDP and provides employment to over $60 \%$ of the population. Indian agriculture has registered impressive growth over last few decades.

Uttarakhand has variety of agro- climatic and biodiversity suitable for numerous agricultural crops. The state has more than 80 per cent of the work directly engaged in agriculture and allied activities. Though only 12.5 per cent of the total land area (approx. $52000 \mathrm{sq} . \mathrm{km}$ ) of is cultivable with only 11 per cent of the total cultivable area is irrigated. A significant part, which is 70.64 per cent of the operational holdings of the hill region are less than one hectare 17.77 per cent are up to 2.0 hectare (Agriculture Statistics at a Glance, 2007). The facts state U.S. Nagar district has a unique existence for high production of cereal crops mainly rice and wheat. But price realization of the growers has been poor due to inefficiencies are across the supply chain leading to poor on one hand and exorbitant prices paid by consumers on the other.

Rice cultivation is of extreme importance to the food security of Asia, where more than $90 \%$ of the global rice is produced and consumed. In India it accounts for $40 \%$ of food grain production, providing direct employment to $70 \%$ area. Being the staple food for more than $65 \%$ of the people, our national food security hinges on the growth and stability of its production.

Agriculture supply chains and their management are now evolving in India to respond to emerging new marketing situations in the wake of globalization. Also, other internal changes like increased disposable income change in the food basket of the consumers towards high value products.

The amended APMC Act, key agricultural marketing act of the country, being implemented by the different states of India, now contains enabling provisions to promote contract farming, direct marketing and setting up of private markets (hitherto banned). These measures will help in achieving economies of scale to the small firms for establishment of direct linkage between primary producers and processors/ exporters/ retailers, etc. Thus, help in establishment of integrated supply chains with both forward and backward linkages.

Efficient supply chains results to an increase in the marketable surplus by bringing down the inefficiencies in production, processing, storage and transportation. Also, farmers are ensured of better prices which encourage them to invest more in order to increase production and productivity. Economic efficiency in a system can be examined as technical efficiency in marketing the produce. Technical efficiency can be increased by minimizing physical losses and improvement of technology to carry out various functions. Bridge (1996) has also studied the supply chain management for fresh vegetable in United Kingdom and concluded that supply chain management is concerned with the linkage from primary producers to the final consumer. The main objective of the supply chain is shown in the diagram as follows-

\section{Materials and Methods}

This study was conducted in the state of Uttarakhand. The state is agriculturally important one among all the newly formed state in the country, in regard to seed production. The study was conducted in 
Udham Singh Nagar district of Uttarakhand for a view of supply chain management of wheat and rice seed production by Tarai Development Corporation Uttarakhand and private seed plant owners. This is to analyze the forward, backward integration of supply chain. Udham Singh Nagar district was selected purposely because it is a major rice and wheat growing belt in Uttarakhand. Secondly, most of the seed growers by the Tarai Development Corporation come from the district. Udham Singh Nagar has huge number of seed companies which are providing seeds to the farmers across India. Thus, most of the farmers were involved in the seed production program of one or other seed company.

The primary data were collected from selected sample farmers, and private seed plant owners through personal interviews. This method was demarcated as most need based, appropriate and feasible for this study, since detailed information was required on package of practices adopted by farmers and reason expressed by the farmers in selecting particular seed producing agency apart from Tarai Development Corporation. Private seed plant owners were interviewed to find the practices followed by them from procurement till the marketing of seeds. Beside this, the secondary data was collected from various published records/ publications and from selected seed producing companies (Fig. 1).

\section{Summary}

\section{Forward linkages in the supply chain}

Tarai Development Corporation has an extensive network of dealers and retailers. These channel partners were present states like Uttar Pradesh, Bihar, Assam, West Bengal and Haryana etc. The large sales channel helps the corporation to cater and fulfill the demands of farmers in various states. Tarai Development
Corporation being the first major public sectors firm hold special value in farmer's mind. Tarai Development Corporation brands 'Pantnagar Seeds' has traditionally been a symbol of quality seeds. Tarai Development Corporation caters its customers to a number of sales channels. These channels are of varied nature. Tarai Development Corporation directly supplies seeds to a farmer and also follows the conventional marketing channel of dealers and retailers. Broadly, these market linkages were divided into Private sales channel, Government sales channel, Institutional sales channel, Private network and Direct sales channel.

\section{Private sales channel}

Private channel of marketing includes the distribution of seeds with involvement of private individuals and firms which helps in increasing the supply of seeds to the farmers. The major benefits of private sales channel over the government sales and institutional channel is there reach and penetration of the farmer. The major objective of these private firms/individuals is to earn financial profits by selling the seeds of Tarai Development Corporation. The private sale channel is divided into two categories.

\section{Channel 1}

$\mathrm{TDC} \longrightarrow$ Dealers $\longrightarrow$ Retailer $\longrightarrow$ Farmers

\section{Channel 2}

$\mathrm{TDC} \longrightarrow$ Dealers $\longrightarrow$ Farmers

Conventionally, these two channels are moreover same in which the dealers/retailers sales the packed seeds to the farmers. The freight expenditure in the transportation of the seeds from the company's warehouses and processing plant is bear by the corporation. But recently after the issues rise in the past, 
the corporation has been selling at the exwarehouse prices. Sales department after receiving the due payments, issues a delivery order which authorizes the dealers to receive the material from the corporation storage facilities. Dealers arrange the distribution facilities by themselves. Once, the material is loaded all the responsibility of the seed lies on the distributors. Thus, new freight policy adopted by the corporation has decreased the risk of any financial loss during the transit of the goods from origin to destination.

In the current scenario of agriculture input marketing, the trend of the firms acting as wholesaler has lost charm. There is an extensive competition within the firms to increase their share of sale. Thus, private seed companies are appointing dealers which even have very low selling and financial capacity. Most of the dealers directly dispatch the material from company's warehouses to retailers point. It helps in saving the unnecessary expense incurred in unloading and loading of seeds at dealer place. Lindgreen and Hingley (2003) have also discussed the measures taken by Tesco Food Company in setting up effective guidelines for managing its relationships with neat suppliers. These guidelines make it possible for serious food scares and to address consumers concern over animal welfare and environmental issues.

\section{Government sales channel}

Government sales channel is another major channel through which Tarai Development Corporation dispose of its products. Most of the seeds sold through this channel are distributed to farmers in subsidy. Seed is provided to various small and marginal farmers by the state government through agriculture departments and primary agriculture cooperative societies. Subsidized seeds help in having the farmers access to quality inputs required for increased seed production. Tarai Development Corporation provides seeds for both Uttarakhand and Uttar Pradesh government.

Cooperatives also provide agricultural inputs to the small and marginal farmers. Recently, cooperative department of Uttarakhand had tied up with Tarai Development Corporation for provision of seeds to farmers through primary agriculture cooperative societies. These societies lift the seeds from the company's storage facilities on the directives issues by state cooperative bodies. Like numerous private seed companies of tarai region, Tarai Development Corporation has also started this practice of selling seeds at exwarehouse prices. Ioanna (2003) has reported the relationship between producer, wholesale and retail prices of Greek agricultural products.

\section{Channel 3}

TDC $\longrightarrow$ Primary Agriculture Cooperative Society $\longrightarrow$ Farmers

\section{Channel 4}

$\mathrm{TDC} \longrightarrow$ State Agriculture Department $\longrightarrow$ Farmers

\section{Institutional sales}

This is the third major sales channel of Tarai Development Corporation. Tarai Development Corporation market and sells its products to various other institutions. These institutions are private, government and public sector undertakings. The corporation grows seed for these companies and the responsibility of marketing lies with the buyer companies. Seeds are sold under the brand of Tarai Development Corporation i.e. Pantnagar seeds. Entering into agreement mutually benefit both firms involved in the agreement. For example, National Fertilizers Limited is 
public sector undertaking under Ministry of Chemicals and Fertilizers which had a tie up with Tarai Development Corporation by which it sells seeds of Tarai Development Corporation through existing fertilizer sales channel.

Tarai Development Corporation is also supplying seeds for the other private seed companies. Private seed companies purchase foundation seeds for the production of certified seeds. Recent changes in the policy of Uttarakhand government have made Tarai Development Corporation responsible for production of foundation seeds.

No other private firm will be allowed foundation seed production (Breederfoundation). This new directive issued by Uttarakhand government will provide new horizons for institutional sales channel of Tarai Development Corporation. Sourcing foundation seeds from Tarai Development Corporation will ensure quality sowing material to farmers who are taking seed program for certified seed production in Uttarakhand.

\section{Channel 5}

TDC $\longrightarrow$ Private Seed Firms

\section{Channel 6}

$\mathrm{TDC} \longrightarrow$ Government Seed Company/PSU

\section{Direct sales channel}

Fourth type of sales channel includes disbursement of seeds to the farmers who take the certified seed production program of TDC. It also includes the sale of certified seeds directly through the counters of TDC and through other seed selling facilities of TDC. Huge quantity of seed of TDC is sold during Kisan Mela at Pantnagar University. Most of the sale is concentrated on certified seeds. It includes a simple movement of goods from TDC facilities to farmers.

\section{Channel 7}

\section{$\mathrm{TDC} \longrightarrow$ Farmers}

\section{Share of marketing channels}

The share of different marketing channels is given in Table 1 . The total quantity of paddy seed marketed through the various channels of Tarai Development Corporation is 42471 quintals. Out of these channels the share of channel I (Dealer- Retailer- Farmer) is highest having a share of 51.45 per cent. It is the conventional sales channel which is found to be most used in seed industry. This was followed by channel II (Dealer- Farmer) through which about 8426 quintal of paddy seed is marketed, having a share of 19.84 percent. Paddy seed marketed though state agriculture department and primary agriculture cooperative societies having a combined share of about 16.8 per cent of the total sales of paddy sales by Tarai Development Corporation. Most of the seed sold under government and cooperative sales channel is provided under subsidized rates. It is followed by direct sales channel having a share of 9.19 per cent in which farmers directly purchase seeds form the retail counters of Tarai Development Corporation. The share of channel VI (Private firms) is 1.73 per cent. Last channel is channel VI having a share of 0.99 per cent and a volume of about 420 quintals. Mundinamani et al., (1993) have used Bain's classification of markets and Lorenz coefficient of inequality techniques. The study revealed that groundnut market is highly and moderately concentrated oligoposonic nature of competition.

In case of wheat seed, share of marketing channel I (Distributor - Retailer- Farmer) is 
29962 quintals which is $59.93 \%$ of the total quantity of wheat seed sold. The channel number II (Farmers) which is having a share of 17.48 percent and quantity of 8739.12 quintals. The combined share of both of these conventional channels is 77.41 per cent with the volume of 38701.12 quintal. The third most important marketing channel is channel VII through which seeds are directly sold to the farmers having a share of $11.32 \%$ with the volume of 5499.45 quintals. It is followed by channel number IV having a share of 2324.76 quintals which is 4.65 per cent of the total wheat seed sold by Tarai Development Corporation. Trondsen (1997) has reported that market barriers for fresh products should be studied in organizations of first hand sale. $\mathrm{He}$ also found that prices vary according to quality and season in fresh fish market. $\mathrm{He}$ showed positive relationship between price, demand, uncertain quality, and unsteady supply in sale. Fearne and Hughes (1999) in his study found that super market strategies, food safety legislation and supply chain intensity, rationalization of the supply base and innovation are the four-key driven the transformation of the fresh produce industry of UK.

\section{Private industry seed supply chain}

Private seed companies are providing a very stiff challenge to the Tarai Development Corporation. This challenge is both in terms of market and supplier base. Operational efficiency of private seed industries is quite higher than that of Tarai Development Corporation. Private seed companies have different capacities varying from very small to very large. Few seed plant owners prefer to take production of foundation seeds (breeder to foundation seeds) on their own land or under their direct supervision. This ensures quality seed production as these foundation seeds are further distributed to farmers of certified seed production. In other situation, foundation seed is also produced at grower's field. Seed companies take a great care in maintaining quality in production of foundation seeds. Burma and Bosilie (2000) where studying the development of a sustainable agri- supply chain. They have reported that conducive condition and prerequisite for commitment is mutual cooperation and benefit. The interest and matching behavior of the various stakeholders in the supply chain for vegetable in Thailand was the appropriate strategy for chain development. The seed is source from various agencies and institution. Most of the seed plant owners are member of seed committee of state agriculture universities and Indian Council of Agricultural Research. Breeder seeds can be directly procured from agriculture universities, ICAR and other agriculture research stations. Seed can also be procured from National seed Corporation. Most important constraint in breeder seed is availability and high cost. Notified varieties which are in great demand are not easily available. Particularly in case of wheat seed where industry is dominated by the search varieties of public institutions. Seed rate of wheat is much higher than that of rice. Thus, foundation seed production program (breeder to foundation) is generally avoided by firms.

Parwez (2013) has studied that Indian agriculture for food security in terms of in adequate infrastructure and highly inefficient supply chain in context of information technology. Due to lack of efficient infrastructure and food processing industry about 30-35 per cent of all foods produced in India are wasted. Seed plant owners only take the production program of varieties which are in great demand. Focus is laid on the varieties which are market leaders. Old Varieties are taken in production program rarely. Estimation of market demand for next season is done with the help of both quantitative and qualitative information. 
Table.1 Quantity of paddy and wheat seeds sold under various sales channel of Tarai Development Corporation

\begin{tabular}{|c|c|c|c|c|}
\hline \multirow{2}{*}{ Marketing Channel } & \multicolumn{2}{|c|}{ Paddy } & \multicolumn{2}{c|}{ Wheat } \\
\cline { 2 - 5 } & Qty. (In quintals) & Percentage & $\begin{array}{c}\text { Qty. (in } \\
\text { quintals) }\end{array}$ & Percentage \\
\hline I & 21851.32 & 51.45 & 29962.00 & 59.93 \\
\hline II & 8426.24 & 19.84 & 8739.12 & 17.48 \\
\hline III & 2633.20 & 6.23 & 1864.81 & 3.73 \\
\hline IV & 4489.18 & 10.57 & 2324.76 & 4.65 \\
\hline V & 734.75 & 1.73 & 1164.88 & 2.33 \\
\hline VI & 420.46 & 0.99 & 279.97 & 0.56 \\
\hline VII & 3864.86 & 9.19 & 5499.45 & 11.32 \\
\hline Total- A & 42471 & 100 & 49995 & 100 \\
\hline
\end{tabular}

Table.2 Quantity of paddy and wheat seeds sold under various sales channels of private seed firms

\begin{tabular}{|c|c|c|c|c|}
\hline \multirow{2}{*}{ Marketing Channel } & \multicolumn{2}{|c|}{ Paddy } & \multicolumn{2}{c|}{ Wheat } \\
\cline { 2 - 5 } & Qty. (In quintals) & Percentage & Qty. (In quintals) & Percentage \\
\hline I & 6745.76 & 62.07 & 42265.92 & 58.43 \\
\hline II & 2426.82 & 22.33 & 19689.85 & 27.22 \\
\hline III & 892.26 & 8.21 & 4448.66 & 6.15 \\
\hline IV & 803.16 & 7.39 & 5931.57 & 8.20 \\
\hline Total & 10868 & 100 & 72336 & 100 \\
\hline
\end{tabular}

Fig.1

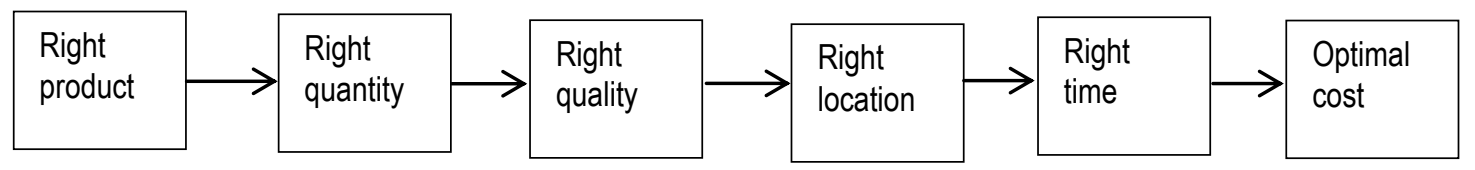

Variety wise sales records are analyzed for past seasons. It helps in finding a trend in the market demand of a particular variety for company. Firms also gather data of other companies in order to estimate the market size.

These figures are used to analyze market trends for each variety. Gupta and Rathore (1999) have conducted a study on disposal pattern and constraints in vegetable marketing in Raipur district. Two supply chains, one from producer to consumer including the wholesaler and retailer and the other directly from producer to consumer were included in this study.

\section{Seed distribution}

Seed distribution is done in two ways. After the farmers are selected, they are asked to lift the seeds from firm's warehouse. The selected 
farmers are mostly present in vicinity of processing plants. Firms also provide a service of home delivery of seeds in which seeds are provided by firms at farmer's doorstep. Farmers who take seed production program in large area are provided with this facility. It may be free or at a very low expense. It is observed that in a village seed production program of only few companies is taken. This figure may be one to three companies operating in a village. Transportation of seeds from warehouses to processing plants is done by trolleys. Villages are selected in such a way that they lie on a single route. Few plant owners also follow a principle of giving only one variety to a farmer also. A principle of taking a single variety for seed production in a village is also observed. Sharma et al., (2013) have reported the practical issues which exist in the supply chain of rice. The study comprised of various issues related to collaboration at downstream end of the supply chain, inventory management, demand consolidation and inventory reduction.

Small seed firms also provide a facility in which raw seeds are taken to their processing plant by themselves. This may be in the form of bags or packed form. Generally, farmers and companies prefer to procure grains in loose form. It saves an additional expense incurred in filling, stitching and loading bags.

The transportation cost for undersize is born by the farmer. Also, standard deduction of one kilo gram per sixty kilograms is made. This is a standard process observed in every grain owner. If the farmer wants to take cash payment, then a cash discount of $1-1.5 \%$ is deducted.

The payment of seeds is made between 10-15 days depending on the policies of firm. Firm which also acts as grain trader also provides facilities of advance payments to farmers and commission. Bestari (2004) has also studied that roads, transportation and communications played important roles in the flow of goods, services, and information in Bangladesh and reported that most $(61 \%)$ of the retailers get their requirements from wholesalers, 15 per cent from the large and other retailers.

\section{Forward linkages}

Seed companies have a very robust sales channel. The sales channels may vary from one firm to another. Dependence on a particular channel may vary but channel identified are moreover same. Private seed firms follow two type of transport system- FOR and Ex-warehouse. In case of exwarehouse channel partners are provided material at firm's warehouse. Rate is quoted to different distributors and retailers. Facilities like cash and quantity discount is also provided to them. Arrangement of transportation is the responsibility of concerned buyer. Market dynamics in seed industry is a crucial factor. There are high chances of delayed payment in case of any change in market scenario. In the rabi season of crop year 2014-15 wheat seed industry saw major turmoil in which payments from dealers of Bihar and eastern UP were delayed. Seed disbursed through the government channel is mostly counted under the institutional sales. Sales channel of private seed companies can be categorized into three categories Private sales, Institutional sales and Direct sales.

\section{Private sales}

The private sales channel is the most crucial sales channel for private seed companies. Reliance of the private seed companies on private sales channel is very high. Private sales channel can further be categorized into two subcategories.

First channel involves the direct movement of seeds from company to retailers. These retailers directly sell the sowing seed material to the farmers. The sales network of a private seed firm is very much similar to that of public firm. The major difference between private and public sector firms that the market functioning and strategy of private is quite aggressive as compared to public firms. 


\section{Channel I}

Seed firm $\longrightarrow$ Distributor $\longrightarrow$ Retailer $\longrightarrow$ Farmer

\section{Channel II}

Seed firm $\rightarrow$ Distributor $\rightarrow$ Farmer

Institutional sales

Private seed companies are also involved in direct sales to other firms. These may be other private seed companies who purchase foundation seeds to feed the demand for their own seed production program.

It also includes sales of certified seeds to other company which markets them under their own brand name. Trend of institutional sales is not much prevalent in survey area as most of the countries prefer their own seeds both for seed program and marketing.

\section{Channel III}

Private seed firms $\rightarrow$ Other seed firms $\longrightarrow$ $\longrightarrow$ Farmers

\section{Direct sales}

Direct sale is the channel in which no intermediary is involved between the firm and the consumers. Framers directly purchase the seeds from the seed plant owners present in the vicinity. This type of channel is only active in tarai regions and adjoining area of Uttar Pradesh.

\section{Channel IV}

\section{Private seed firm $\rightarrow$ Farmers}

\section{Share of marketing channels}

The share of different marketing channels is given in Table 2. The share of Channel I and II which is the conventional sales channel is 84.4 per cent of the total sales of paddy seeds. It is followed by Channel III and IV which have a share of 8.21 per cent and 7.39 per cent in case of wheat seeds, the share of Channel I is maximum which is 58.43 per cent of the total sales. It is followed by Channel II in which distributors directly sells to farmers, having share of 27.22 per cent. Macfadyen et al., (2005) have reported in a field study on the milkfish value chain in the Philippines indicated that loss during marketing is more severe than loss during production.

Galli et al., (2015) have studied that over the 2000s', consumers' food purchases have been increasingly informed by supply chain-related issues, with growing concerns about the sustainability of chains differing for their geographical scope. As a result, short food supply chains and local food systems have risen to policymakers and food chain stakeholders' attention as more sustainable alternatives to mainstream food networks.

\section{References}

Ayieko, M.W., Tschirley, D.L. and Mathenge, M.W., 2005. Fresh fruit and vegetable consumption patterns and supply chain systems in urban Kenya: implications for policy and investment priorities. Development Policy Rev., 28 (7): pp.212-230.

Bestari, N. 2004.Special evaluation study on small-scale freshwater rural aquaculture development for poverty reduction. Asian Development Bank Operations Evaluation Department. SST: REG 2004-07. pp.1-55.

Bridge, D.S. 1996. Supply chain management for fresh vegetables: The key success factor from the producers point of view. Farm Management. 9(7): pp.347-354.

Browne, M., Riezt, C., Anderson, S., Allen, Z. and Keita, B. 2005. Life cycle assessment in the supply chain. Transport Reviews. 25(6): pp.761-782.

Burma, E.S. and Boselie, D.M. 2000. Stakeholder perception analysis for 
Agri- Supply Chain development.Acta. Hort. 536: pp.625-633.

Fearne, A. and Hughes, D. 1999. "Success factors in the fresh produce supply chain: insights from the UK". Int. J. Supply Chain Management.4(3): pp.120129.

Galli, F., Bartolini, F., Brunori, G., Colombo, L., Oriana, G., Grando, S. and Marescotti, A. 2015.Sustainability assessment of food supplychains: an application to local and globalbread in Italy. Agricultural and Food Economics. 3:p.21.

Gokarn, S. and Kuthambalayan, T.S. 2019. Creating sustainable fresh produce supply chains by managing uncertainties. Journal of Cleaner Production. 207: pp.908-919.

Gupta, S.P. and Rathore, N.S. 1999. Disposal pattern and constraints in vegetable market: A case study of Raipur District of Madhya Pradesh. Agric. Mktg. 42 (1): pp.53-59.

Ioanna, R. 2003.An investigation into the relationship between producer, wholesale and retail prices of Greek agricultural products. Centre of Planning and Economic Research, No 80.September. Hippokratous Street, 106 80 Athens.

Kellya, K., Madden, R., Emond, J.P. and do Nascimento Nunes, M.C., 2019. A novel approach to determine the impact level of each step along the supply chain on strawberry quality. Postharvest Biology and Technology.147: pp. 78-88.

Lindgreen, A. and Hingley, M.K. 2003."The impact of food safety and animal welfare policies on supply chain management: the case of the Tesco meat supply chain", British Food Journal. 105(6): pp. 328-349.

Macfadyen, G., Philip, S. and Haylor, G. 2005.Output three synthesis report with poor trade research findings of policy recommendation, Bangkok. Poseidon Aquatic Resource Management Ltd. NACA - Stream.

Mundinamani, S.M., Sastry, N.R. and Murthy Shankar, H.G., 1993. Market structure for oilseeds in Karnataka - A case study of groundnut. Ind. J. Agric. Marketing. 7(2): pp.201-212.

Parwez, S. 2013. Food supply chain management in Indian Agriculture: Issues, opportunities and further research.

Poot, E. H., Dekker, P.A.R., Jonkman, B. and Splinter, G.M. 2000.Chain information to support Dutch Supply Chain effectiveness. Acta Hort.536: pp. 645650.

Sharma, V., Giri, S. and Rai, S.S. 2013. Supply Chain Management of Rice in India: A Rice Processing Company's Perspective. International Journal of Managing Value and Supply Chains. 4(1): p.25.

Shukla, M. and Jharkharia, S. 2013.Agri-fresh produce supply chain management: a state-of-the-art literature review. International Journal of Operations \& Production Management. 33(2).

Trondsen, T. 1997. Marketing potential and barriers for fresh packed fish. A survey of buyer perception in UK and French Seafood distribution. Journal of Food Products Marketing. 4(2): pp.79-99.

\section{How to cite this article:}

Nikhil Pratap Singh, Sarbananda Sahoo and Chandra Dev. 2021. Supply Chain of Paddy and Wheat Seeds Production in Tarai Development Corporation and Private Seed Firms of Uttarakhand. Int.J.Curr.Microbiol.App.Sci. 10(02): 2701-2710. doi: https://doi.org/10.20546/ijcmas.2021.1002.298 